\title{
Organizational Climate Prevailing in Al-Balqa Applied University / Faculty of Princess Alia University from the Viewpoint of the Faculty Members: Case Study
}

\author{
Dr. Bashir Arabiyat \\ Al.Balqaa Applied University, Jordan \\ E.mail: arabiyat3636@yahoo.com
}

Accepted: October 21, 2011 Published: November 27, 2011

doi:10.5296/ijhrs.v1i2.1116 URL: http://dx.doi.org/10.5296/ijhrs.v1i2.1116

\begin{abstract}
This study aimed at investigating the prevailing organizational climate at Al-Balqa Applied University $\backslash$ faculty of princess Alia University from the viewpoint of the faculty members. The study population consisted of all faculty members at the faculty of princess Alia University whom count (80) individual. In order to collect the study data, a questionnaire was designed based on previous studies. The study showed that the overall mean for the organizational climate prevailing in Al-Balqa Applied University / Faculty of Princess Alia University from the Viewpoint of the Faculty Members has reached (3.32) and standard deviation (1.00), with a degree of importance of moderate. Results also showed that the field of personal relationships came in the first rank; while the field of affiliation ranked last. The study recommended creating an effective system of incentives in the university, in order to improve the satisfaction of faculty members for their jobs, which contribute to a organizational climate, which facilitates work processes, achieving the objectives of the university.
\end{abstract}

Key Words: Organizational Climate, Al-Balqa Applied University, Faculty of Princess Alia University, Faculty Members

\section{Introduction:}

Organizational climate is one of the important concepts in the sociology of work; because of its impact in the identification of organizations seek to high productivity and employee satisfaction at the same time. The fact that universities are entities targeted social, they play an important role in accelerating the pace of development in developing and developed countries alike, and which is the scientific study is how to strengthen the role 
of these universities are helping to increase their effectiveness in achieving social and economic objectives assigned to it.

The success of any university in any system is related to many variables that would contribute in achieving that success. The nature of work within the university and the social relations and interactions between workers - like any other organization - play a major role in achieving the objectives pursued by the administration, is accompanied by the success of organizations and institutions with a large number of organizational variables. One of the most important variables is the organizational climate (Nashwan, 2008).

The organizational climate is related to the type of human relations prevailing in the job, which contribute to the achievement of the objectives, drawing on the human effort, and resources available. The climate is not determined through procedures, laws and regulations of the organization; but through a set of relations and communications, and interactions between individuals (Hakimi, 2008).

The creation of sound organizational climates is not linked to social and economic aspect, but is a state of civilized intellectual cultural psychology, the dependent and continuous interaction between these aspects requires an accurate calculation and a clear vision (Natur, 2009).

\section{Study Problem:}

The interest in organizational climate at educational institution creates the faculty members the desire and motivation to work for the achievement of educational goals, no doubt that the faculty member is considered a cornerstone in the educational process as a tool of effective and supportive core of the educational process, as reflected in the prevailing climate experienced by the faculty member on the degree of satisfaction they have, and therefore the behavior is positive, as the lack of a positive organizational climate and appropriate direct affects significantly the performance of the university.

It can be said that the problem of this study is to answer the following main question:

What is the level of organizational climate prevailing in Al-Balqa Applied University / Faculty of Princess Alia University from the viewpoint of the faculty members?

The ramifications of this question the following sub-questions:

1. What is the level of organizational structure prevailing in Al-Balqa Applied University / Faculty of Princess Alia University from the Viewpoint of the faculty members?

2. What is the level of work procedures prevailing in Al-Balqa Applied University / Faculty of Princess Alia University from the Viewpoint of the faculty members?

3. What is the level of incentives prevailing in Al-Balqa Applied University / Faculty of Princess Alia University from the Viewpoint of the faculty members?

4. What is the level of affiliation prevailing in Al-Balqa Applied University / Faculty of Princess Alia University from the Viewpoint of the faculty members?

5. What is the level of personal relationships prevailing in Al-Balqa Applied University / Faculty of Princess Alia University from the Viewpoint of the faculty members? 
Study Importance:

2011, Vol. 1, No. 2

The study importance can be identified by the following:

1. The study highlights the importance of the organizational climate, which is one of the key variables that significantly affect the work in the business organizations and universities alike, as reflected on the most direct reflection of the working mechanisms of the Organization.

2. The importance of the study comes from the importance of the study sample, as a faculty member in the basic building block of any educational institution, and is based upon the university to achieve the objectives set.

3. The importance of the study also, can be identified from the importance of universities, which are based upon our access to students and learners are aware of and live up to society and the state as a whole to refineries educationally advanced countries, because of their prominent and influential role in the advancement and continued development.

4. The findings of the study may contribute as a feedback for decision makers, in order to stand on the level of organizational climate in Al-Balqa Applied University / Faculty of Princess Alia university to identify the strengths of them, and try to encourage and invest, and verification of vulnerabilities and develop plans to avoid them to reach the best level of organizational climate.

\section{Study Limitations:}

The current study was limited by the following:

1. Time limits: This study was conducted in the academic year (2010-2011).

2. Place Limits: this study was conducted in Al-Balqa Applied University / Faculty of Princess Alia University.

3. Objective limits: the results of this study will be determined by the response of faculty members of the study sample clauses tool of the study.

\section{Theoretical Framework and Previous Studies}

Al-Natur (2009) conducted a study aimed at identifying the effect of organizational climate on the performance of private hospitals in Jordan. The study population of all major private hospitals in the capital Amman, and resident patients, where the study sample included managers and department heads of their number (235), and (360) of patients resident in all hospitals. Two questionnaires were used for the purpose of collecting data of the study, the first to measure the organizational climate in hospitals mentioned; and the second questionnaire was to measure patient satisfaction with services in these hospital. The study found that all the elements of organizational climate except the incentives and rewards have an impact on performance.

A study conducted by Al-Hakimi (2008) aimed at identifying the organizational climate prevailing in schools of basic education and its relationship to job satisfaction for teachers in the city of Taez. The study population of teachers in basic education schools in the city of Taez (4251) teachers, and included the study sample (298) teachers. A questionnaire 
was developed to identify all the data from members of the study sample depending on (Organizational Climate Description Questionnaire).The study found that the overall level of the regulatory climate prevailing primary school in Taez is located at a low level, and the field affiliation won first place in the behavior of teachers.

Nashwan (2008) conducted a study aimed to investigate the organizational climate in the Jordanian Telecommunications Company from the perspective of workers. The study sample consisted of (200) employees in the Jordanian Telecommunications Company. A questionnaire has been designed for the purpose of collecting data from members of the study sample. The study found that the tendency of individuals to the study sample was negative organizational climate as a whole, except for the fields of technical skills and objectives was positive.

A study conducted by Hamid \& Ramazan (2007) aimed to identify the organizational climate at the University of Kerman in India for the staff and compared with the climate is desirable. The study sample included (262) employees from the total number of staff of the University's (820) employees. The study found similarities between the organizational climate of the university system (Halpin \& Croft) for members of the organization and conduct of the regulatory terms of separation, barrier, and of belonging and intimacy, as well as also for the behavior of management in terms of isolationism, production and payment for, and observance.

Also, Srivanstav (2006) conducted a study aimed to discover the motives of organizational climate in terms of character, and role-related stress, and the strategy of treatment, and personal variables. Data was collected from the (155) as Executive Director in the manufacturing sector in the U.S. through the questionnaire. The study, to consider the organizational climate index is important and the president compared to market share, sales and turnover, and profitability of organizational performance measurement.

Fu-eheng Chien (2006) conducted a study aimed to explore the relationship between the behavior of leaders and organizational climate, the impact and effectiveness of managers in the vocational training centers. Also, the study aimed at identifying the types of leadership behavior and organizational climate that lead to effective leadership. The study sample consisted of nine Career Centers, where the total number (178) individuals, where responding to a questionnaire study. The study found that organizational climate was moderate at vocational training institutions of the State, and that the transformational behavior of managers was high, and vocational training centers have the capacity and effectiveness of large, ambitious and that the motivation was also high in these centers.

\section{Methodology of the Study}

\section{Study Population and Sample:}

The study population consisted of all faculty members working in the Al-Balqaa University $\backslash$ Faculty of Princess Alia University. Their number was (80) in the academic year (2010-2011). Due to the small population of the study, all the study population was taken as a study sample. Thus, the study sample consisted of (80) members of the faculty. 
Tools of the Study:

The researcher developed a questionnaire depending on the theoretical literature and previous studies. This questionnaire consisted of five fields with multiple items, to identify the prevailing organizational climate in Al-Balqa Applied University / Faculty of Princess Alia University from the viewpoint of the faculty members.

\section{Validity and Reliability:}

Verified the authenticity of the study tool, and that offer a number of academic specialists in the field of study, to make sure the language of the paragraphs and their suitability for the domain that put into it. It also confirmed the stability of the tool of the study, through testing and retesting, where questionnaire was distributed to a sample reconnaissance, and then distribute the questionnaire two weeks after these individuals, and the extraction factor values (Chronbach alpha) to make sure that the degree of stability of an instrument of the study, which demonstrated the value of coefficient Chrombach alpha for the study variables between (0.81-0.94), and this value is acceptable for the purposes of this study as higher than the minimum and stability of (0.60).

\section{Analysis of Study Data:}

Likert scale was used to answer the items of the questionnaire based on the following values: strongly agree (5) points, OK (4) points, agree somewhat (3) points, but OK (2) points, is strongly Disagree (1) point, where it was divided into the following categories:

- $1-2.33 \rightarrow$ low.

- 2.34-3 $66 \rightarrow$ moderate.

- $3.67-5 \rightarrow$ high.

\section{Results of the study and Discussion:}

Means and standard deviations were calculated for the answers to the members of the sample to answer the study questions.

\section{Answering the study questions:}

This part was to answer the study questions, as follows:

What is the level of organizational climate prevailing in Al-Balqa Applied University / Faculty of Princess Alia University from the viewpoint of the faculty members?

Table (1)

Arithmetic means and standard deviations for the total fields of organizational climate

\begin{tabular}{|c|c|c|c|c|c|}
\hline No. & Item & $\begin{array}{c}\text { Arithmetic } \\
\text { Mean }\end{array}$ & $\begin{array}{c}\text { Std. } \\
\text { Deviation }\end{array}$ & Rank & $\begin{array}{c}\text { Importance } \\
\text { Level }\end{array}$ \\
\hline 1 & Organizational Structure & 3.19 & 0.97 & 3 & Moderate \\
\hline
\end{tabular}




\begin{tabular}{|c|l|c|c|c|c|}
\hline \hline $\mathbf{2}$ & Work Procedures & 3.76 & 0.85 & 2 & High \\
\hline $\mathbf{3}$ & Incentives & 2.90 & 1.04 & 4 & Moderate \\
\hline $\mathbf{4}$ & Affiliation & 2.87 & 1.24 & 5 & Moderate \\
\hline $\mathbf{5}$ & Personal Relationships & 3.91 & 0.90 & 1 & High \\
\hline & Total Arithmetic Mean & 3.32 & 1.00 & - & Moderate \\
\hline
\end{tabular}

It is clear from the previous table, that the overall mean for the organizational climate prevailing in Al-Balqa Applied University / Faculty of Princess Alia University from the Viewpoint of the Faculty Members has reached (3.32) and standard deviation (1.00), with a degree of importance of moderate.

Results showed that the field of personal relationships came in the first place arithmetic mean (3.91) and a standard deviation (0.90). The field of affiliation ranked last with arithmetic mean of (2.87) and a standard deviation (1.24).

This result differs from the result of Al-Hakimi (2008) which found that the overall level of the organizational climate prevailing in primary school in Taez is located at a low level. Also, it differs from the result of Nashwan (2008), which found that the tendency of individuals to the study sample was negative organizational climate as a whole.

\section{Recommendations:}

On the light of the study results, the study recommended the following:

1. Creating an effective system of incentives in the university, in order to improve the satisfaction of faculty members for their jobs, which contribute to a organizational climate, which facilitates work processes, achieving the objectives of the university.

2. Continuous meetings between faculty members, thus contributes in enhancing personal relationships, thereby enhancing the educational process and maintains the proper organizational climate at the university.

3. Conducting further studies to examine the organizational Climate prevailing in different universities and organizations. 


\section{References:}

Fu-Cheng, Cheien (2006). The Relationship Among Leadership Behaviors Organizational Climate and Leadership Effectiveness of Vocational Training institutes Excutive of State Owned Enterprise, Abstract, URN, (etd-06/3/07-113547).

Hakimi, Hakim Abdullah Saif (2008). Organizational climate prevailing schools of basic education and its relationship to job satisfaction for teachers in the city of Taiz. Unpublished Master Thesis, University of Aden, Yemen.

Hamid, R. \& Ramazan, J. (2007). The Organizational Climate of Kerman, Shahid Bahonan University, Public Personal Management, Vol. 34, Issue 3, PP. 247-260.

Nashwan, verses Jibril Jaber (2008). Regulatory climate in Jordan Telecom from the standpoint of employees: a field study. Unpublished Master Thesis, University of Jordan, Amman, Jordan.

Natur, Nawaf Abdul Rahim Mustafa (2009). The impact of organizational climate on the performance of private hospitals in Jordan. Unpublished $\mathrm{PhD}$ thesis, Amman Arab University for Graduate Studies, Amman, Jordan.

Srivanstav, A. (2006). Organizational Climate as a Dependent Variable, Journal of Management Research, Vol. 6, No. 3, PP. 125-136. 